\title{
THE INCLUSION OF NON-TENURED STAFF IN INSTITUTIONAL QUALITY CULTURE
}

\author{
Agnese Rusakova, Sanita Baranova \\ University of Latvia, Latvia
}

\begin{abstract}
The paper is reviewing an array of recent literature sources arguing that the Neoliberalism and the New Public Management are the driving forces behind the observable increase in numbers of terminated employments in several countries in recent decades. The further focus of the literature review is on recent researches suggesting that the non-tenured staff members tend to have less pedagogical skills and are excluded from the internal quality culture.

The synthesized findings of the both review sections suggest that the inclusion of the non-tenured staff into the institutional quality culture can augment the quality of higher education. This constitutes the core motivation for the authors to further research within this article whether the tendencies of increasing share of non-tenured staff members can be identified in Latvia as well. The empirical section of this article is based on statistical analysis of data from different reliable sources.

The study suggests that due to shrinking higher education market and necessity to handle the impact of 2008-2012 Economic crisis, the share of academic faculty staff is being consolidated around the core elected faculty staff.

Nevertheless, it is important to consider a timely inclusion of the non-tenured staff into the institutional quality culture. However, in view of recent higher education reforms and new academic career model being introduced, it is hard to predict the further dynamics of the non-tenured positions in higher education of Latvia. This paper is an effort to start filling the existing research gap in the emerging but under-researched subject of non-tenured staff in Latvia.
\end{abstract}

Keywords: internal quality culture, managerialism, neoliberalism, non-tenured staff, university.

\section{Introduction}

This study builds upon fusion of the following hallmarks of recent higher education developments - the changes in higher education as imposed through neoliberal mindset, the defining ideology of postmodernity (Lethbridge, 2015); the increased attractiveness of non-tenured staff which is further strengthened through recent economic and social developments; 
the changing landscape of education with focus shifting from the teacher to the learner; as well as studies suggesting that the non-tenured staff in education have knowledge and skills gaps to approach these developments accordingly and deliberate actions in form of professional development measures have to be taken to include them advisedly within the institutional quality culture.

\section{Neoliberalism shapes the higher education}

From the 1980s onward, rooted in neoliberal consciousness, countries worldwide introduced reforms that were marked by the term New Public Management and were aimed at improving the efficiency of public sector organizations, based on the concepts of economic rationality (Hood, 1995) and managerialism (Osborne, Radnor, \& Nasi, 2013). Increasingly, the ideology, or a system of values and beliefs, as well as techniques and practices, were borrowed from the private sector and adopted to the public-sector realities.

With New Public Management expanding across different world regions and public sectors, it also affected the governance of higher education (Alves, \& Tomlinson, 2020).

In strive for greater efficiency the governments around the world sought to hold publicly funded institutions more accountable for their outcomes in an effort to improve their performance (Ortagus, Kelchen, Rosinger, \& Voorhees, 2020) and increase own accountability towards taxpayers (Brignall, \& Modell, 2000).

Acting within the context and framework of performance-based funding induces profound changes in higher education institutions.

In order to comply with the governmental requirements and compete with other higher education institutions for the eventual ex post funding amount, the institutions cascade the competitive conditions downward to other institutional levels, to faculties, departments, degree programs (Madsen, 2020). Unavoidably the performance indicators become proxy measures as they inter alia reduce complex phenomena to one or more concrete measures through a process of selection and simplification (McCormick, 2019).

\section{The increased attractiveness of non-tenured staff}

The basic statistics in higher education reveal that the neoliberal academic labour market is highlighted by increase in non-tenured teaching positions, which is expected to further increase (Jaschik, \& Lederman 2015).

The factors that led to this change are complex (e. g., new institutional types, declining appropriations and revenues, greater demand for flexibility, 
the emergence of new disciplines, and the massification of higher education) (Kezar, \& Maxey, 2014). Universities respond to these challenges by employing more staff on sessional contracts (Harvey, \& Jones 2020).

The impact of recurring economic crises, as well as inequalities in money supply due to changing funding periods of different programs, produce fluctuating funding patterns, that further exacerbate the problem. Due to the instability of funding lines many institutions increasingly refuse to make long-range commitments to faculty.

Moreover, the higher education sector as a rule of thumb employs highly qualified staff members, which are too readily absorbed by the competitive environment of the mobile labour force.

\section{The changing landscape of education}

Apart from the already mentioned rise of neoliberalism and knowledge economy Savic (2020) emphasizes other factors such as the 2008 global economic crisis, Fourth Industrial Revolution, the 2020 COVID-19 pandemic, the continuing emergence of online learning, the amount of student debt, and employers' dissatisfaction as dramatic global socio-economic transformation drivers that challenge the traditional university models and generate pressure to reconsider global higher education systems. Hence in 2018 the "learning to learn" is still considered one of the key competences by the European Commission to successfully address the challenges of the $21^{\text {st }}$ century and therefore the twenty-first century curriculum has to address them (Erstadt, \& Voogt, 2018).

The teaching practices are reframed to serve student learning (Rege, \& Nicole, 2017) and the role of the teacher changes as teachers differentiate their instruction strategies (Valli, \& Buese, 2007).

\section{The non-tenured staff in education}

The increasing (versus tenured faculty) share of the non-tenured faculty enters classrooms and faces contemporary student body of post massification, internationally mobile (Shields, 2019) and diverse through both higher education access (Tight, 2019) and equity of access measures (McCowan, 2016).

Majority of the non-tenured staff, due to their average age, have grown up with front-lectures themselves, so instructing the present-day students becomes a challenge.

Various researches have found that non-tenured track faculty members do not use learner-centered teaching practices (Kezar, 2013), and do not get the preparation, furtherance that they require to perform their job (Nica, 2018). 


\section{Method}

An array of recent literature articles suggests that countries that are impacted by the efficiency driven Neoliberalism and the New Public Management (which attempts to manage the public sector through neoliberal ideology), cause an increase in numbers of non-tenured staff members.

Further range of recent publications in the field stresses that the educational landscape is changing, and that the non-tenured staff members tend to have less pedagogical skills necessary to address these changes properly.

These detected trends were further merged to reveal the relevance and topicality of inclusion of non-tenured staff in the internal quality culture, suggesting that the inclusion of the non-tenured staff into the institutional quality culture can augment the quality of higher education.

The higher the share of non-tenured staff, the higher the impact potentially on the institutional teaching quality can be achieved by deliberate inclusion of the non-tenured staff within the internal quality culture.

This constitutes the core motivation for the authors to further research within this article whether the tendencies of increasing share of non-tenured staff members can be identified in Latvia as well and specifically at the University of Latvia.

The empirical section of this article is based on statistical analysis of data from different reliable sources, as well as based on consultations with respective administrative departments of the university.

Based on discovered share of non-tenured staff members and its dynamics - one will be able to conclude whether the deliberate involvement of the non-tenured staff in internal teaching quality culture at the University of Latvia may wield a substantial improvement of the teaching quality at the university and thus comprise a means for internal improvement of quality that should be further examined.

Due to existing research gap on non-tenured staff in Latvia, it was important to identify the national stand as per international developments. It has to be stated that the comparative analysis of developments related to non-tenured staff among different countries is a difficult task due to the tight embedment of the concept in local framework, the various terms used and contextual heterogeneity.

Apart from the "tenured" and its opposite concept - "non-tenured" (Benson, Probst, Jiang, Olson, \& Graso, 2020), which is quite widely used in the academic circles, to demonstrate the complex inherent academic culture and speak of highly diverse national, regional, institutional labour policy intensive context, the academic community applies a wide range of distinctions - "part-time (part-timers), adjunct" (Xu, 2019), 
"casual" (Narayan, 2020), "sessional staff" (Broadbent, 2018; Harvey, \& Jones, 2020), to denote a non-permanent staff member in higher education from the core personnel.

In this paper the authors have used the concept "tenured" and "non-tenured" as it emphasizes the permanency of the working relations and refers also indirectly to the exclusion from the traditional, specific academic career path (lecturer to professor).

However, one has to remember that the ambiguities in terms, gaps in present research agendas, pluralism of ideas - they all result in vague distinctions and cross-cut each other in manners that are still unclear and should be addressed through further researches in the field.

In this paper the authors do not reveal the concept of "internal quality culture" in details. In compliance with the aim of this paper it generally comprises the internal institution-specific approach to quality assurance in teaching, with professional development measures being one of the tools of its formation. Since the quality assurance and quality management are central challenges in the governance of higher education institutions, the paper relates to the issues of collegiality and managerialism.

\section{Results}

\section{Non-tenured staff in Latvia}

Within the previous study, the author has found indications that the New Public Management is shaping the higher education sector in Latvia managerialism seeks to replace collegiality in governance. The performance-based funding has been recently introduced in higher education sector to improve the efficiency of the system. Structures within higher education institutions are created to ensure that each structural unit works towards reaching the institutional performance indicators that are linked to the governmental funding. Also factors that lead to this change are pertinent to the case of Latvia - changes in institutional types are conducted, appropriations and revenues are declining, there is a greater demand for flexibility, the higher education is being massified.

Similarly, like implied in analyzed articles, also in Latvia

"Salaries for per-hour contracts are comparatively low, and HEIs appear to use per-hour contracts to cope with the volatility of institutional income in the Latvian higher education system," (Arnhold, N., Pekkola, E., Püttmann, V., \& Sursock, A., 2018, p. 184).

Indeed, as we will see below, the per-hour contract faculty staff is first to go in difficult times.

Simultaneously, the involvement of per-hour contract faculty staff in Latvia is often connected with other than pure cost-saving considerations. 
"Doctoral students and recently graduated researchers with doctoral degree should be involved," to renew the staff, or "sectoral experts should be involved in applied study courses on per-hour contract basis," to improve the knowledge delivery to the students on sector specific issues (University of Latvia, 2017, p. 38).

The reviewed publications state that neoliberal academic labour market is characterized by increase in non-tenured teaching positions. There are secondary sources, albeit not recent, confirming the trend of increasing non-tenured faculty staff numbers also observable in Latvia.

"Increasingly, teachers that do the teaching as a side job and teachers on per-hour contract are involved in the training process. They are usually top-class specialists in their field," (Riga Technical University, 2010, p. 4).

In the introductory part of this paper the reviewed publications found that the non-tenured faculty staff members lack modern teaching skills. There are indications that the allegation that the non-tenured staff would need to be included in internal quality culture holds true also for Latvia.

“..in Latvia a large part of the academic staff is on per-hour contract who are good or even excellent experts or scientists, but have never studied didactics in their lives." (LETA, 2013).

Thus, many of the prerequisites for the generalizability of the findings of the reviewed literature are met, to suggest that in Latvia the number of non-tenured staff could be increasing as well. However, there is no straightforward statistical information available on the target group of this article - the "non-tenured" academic staff of Latvia.

"Regardless of the high staffing autonomy of Latvian HEIs on paper, the national framework is substantially steering the recruitments, salaries, positions, and ranks of academics" (Arnhold et al., 2018, p. 182).

The system level regulations distinguish the progression of academic staff between academic track (assistant, lecturer, docent/assistant professor, associate professor, and professor) and research track (research-assistant, researcher, and leading/senior researcher). There is no civil servant status-based tenure system in Latvia.

"According to the recent ruling of the Constitutional Court international law could be applied to time practice for the Latvian system, according to which the docent could be identified with an assistant professor, and that would be the post for a fixed term, but the positions of associate professor and professor could be considered as predictable careers model posts" (World Bank, 2020, p. 16).

Therefore, to identify the non-tenured faculty staff dynamics it is important to study the staff numbers of academic track, with "associate professor, and professor" representing the tenured faculty staff and the "assistant, 
lecturer, docent/assistant professor" representing the non-tenured staff members. Apart from these, the legislative framework foresees "visiting academics" and academics on per-hour contracts. The statistics is important to see whether the global trend of increasing share of non-tenured faculty workforce is valid in Latvia as well.

However, it is important to note that

"in contrast to other higher education systems, most academics in Latvia do not hold one (full-time) position for which a certain, more or less stable task portfolio is defined" (Arnhold et al., 2018, p. 183).

The academic staff can hold one position from each track at the same time, as well as have several administrative positions of differing workload added on top of it. Thus, there are many individual combinations of positions possible that seldom remain stable over time due to close connection between source of funding and the type of position.

"HEIs frequently renegotiate the contracts with their academics - three times per year on average at one institution". (Arnhold et al., 2018, p. 207).

These workload portfolios are reassembled as soon as the external funding changes due to decrease in tuition fee paying students or acquiring of an externally funded research project.

"The need to combine different positions and tasks can easily lead to high workloads, particularly if there are sudden changes in work portfolios".

(Arnhold et al., 2018, p. 184).

The division of academic staff in academic and research staff, the combination of full workload by tasks under different positions, and the frequent changes in contracts impede the acquisition of reliable statistical data on personnel in general.

Since the academic staff in Latvia basically works on terms of common national Labour Law, the Central Statistical Bureau collects information on academic staff in their main/primary workplace (the employer of primary workplace may restrict working in any secondary workplace if this right is fixed in the contract and/or collective agreements). However, this information does not distinguish between academic and research track and cannot be used to draw unequivocal conclusions on the dynamics of non-tenured faculty staff (Central Statistical Bureau, 2020).

The Ministry of Education and Science, even though collects information on academic personnel according to both progression tracks, however has published only statistical data reports of years 2018 and 2019 (Ministry of Education and Science of the Republic of Latvia, 2020a). Using these reports the data between the two years cannot be compared with each other due to different set of information represented in both reports (Ministry of Education and Science of the Republic of Latvia, 2020b, 2019). 
Therefore, currently it is impossible to retrieve the statistical information characterizing Latvia from secondary sources.

I. Leduskrasta, Deputy director of the Department of Student Services, (Personal communication, July, 2020) provided the authors with the set of official statistics of the University of Latvia for the period 2011-2020, that are collected and forwarded to the Ministry of Education and Science every year in October (10 years).

The abovementioned statistics show that the number of "associate professor, and professor" has remained relatively stable throughout the years 2011-2020, fluctuating between $-4 \%$ till $+6 \%$ each year. When compared to year 2011, the number of "associate professor, and professor" has grown by $5 \%$, whereas the summarized number of "assistant, lecturer, docent/assistant professor" has dropped by $14 \%$, with the number fluctuating between $-40 \%$ and $+21 \%$ at its extremes. When analyzing the number of total academic track staff, within the last 10 years the number has dropped by $5 \%$.

The number of the visiting professors, visiting docent/ assistant professor and visiting lecturers (containing also the foreigners) has fluctuated with decreased tendency and dropped from 107 in 2010 till 2 in 2020.

The abovementioned data does not provide separately information on faculty staff members on per-hour contract. To get this data a central university level one has to retrieve the information and process the data by applying an extensive effort, analyzing the different contracts of individual task and position portfolios of the employees. The authors have to rely on statement provided by A. Bekeris, statistician for the Department of human resources, (Personal communication, July, 2020) that the number of such faculty staff is non-significant.

Interestingly, the Development Strategy of University of Latvia in 2004 for the period till 2015 was supportive of short term and per-hour contract faculty staff involvement for updating and diversifying the study process with applied knowledge (University of Latvia, 2004). The later strategies do not explicitly address the employment of short term and per-hour contract faculty staff.

Nevertheless, as demonstrated above the analyzed statistical data of the University of Latvia show a reduction in junior faculty staff numbers. This reduction was mitigated by both the demographic and the economic crisis, which both had an influence on the university's performance in the analyzed period 2010-2020.

The higher education market is shrinking - the student numbers experienced $23 \%$ drop within last 10 years. The number of students at the University of Latvia has dropped by $16 \%$ in the period.

The university reacted to the onset of the grave economic crisis in $2008 / 2009$ with decision to increase the student groups per teacher and 
make the most out of the elected academic staff, ensuring that only exceptional minimum of per-hour contract faculty staff is employed hereinafter (University of Latvia, 2008). This purposeful consolidation of academic faculty staff body is also reflected in the statistical data above.

"Since academics do not necessarily have a full-time position at one HEI, they might have to top up their salaries to make a decent living. That is

why many of them have side jobs." (Arnhold et al., 2018, p. 184).

Apart from decrease in staff numbers, the both crises have also promoted shift in workload. 10 years ago $63 \%$ of academic staff were holding one full workload position, whereas in 2020 only $12 \%$ hold one full workload. While 10 years ago $4 \%$ of academic staff were holding workload less than 0,25 , whereas in 2020 the share of such academic staff is $34 \%$. The possibility that the academic staff will be able to cover the living expenses by not accepting side jobs is rather limited due to academicians having ".. low salaries, especially compared to Western countries,” (Arnhold et al., 2018, p. 189).

\section{Discussion}

With regard to the responsiveness of the management on the inclusion of the non-tenured staff within the internal quality culture, there are two pitfalls to be considered - tendency to treat the non-tenured staff as the highly variable share of the human resources and therefore hard to influence, as well as the minor share of the human resources and therefore having no substantial impact upon the quality culture of the higher education. The concluded literature review implies that it is important to regard the non-tenured faculty staff as standalone target group for professional development measures.

However, to begin with, one has to be aware of the non-tenured staff members to engage them in quality related measures.

There are considerable difficulties to find the statistics on the non-tenured faculty staff. This is inter alia due to fact that "a tenure track model, as is common in Western but also neighboring countries, does not exist in Latvia" (Arnhold et al., 2018, p. 164), at least not the tenure in the sense of civil service. Therefore, while looking for available statistics the potential proxies need to be explained. While explaining, whenever possible, it is necessary to rely on existing findings of the recent trustworthy international comparative analyses of the local system. The recent World Bank research on Academic Careers in Latvia (Arnhold et al., 2018; World Bank, 2020) was one of the important secondary sources to be related to.

In addition to differences in notions that have to be tackled, the publicly accessible sources of general statistics on academic staff in higher education in Latvia are very scarce. 
Also at the centralized institutional level information on the short-term faculty staff data is not freely available, meaning that this target group is not institutionalized. There is a decentralized approach and reliance on collegiality-based involvement of non-tenured staff members in institutional quality measures.

From the University of Latvia case alone one can not draw conclusions on the stand in Latvia, as the University of Latvia is the largest national public university. It might be interesting to further analyze data from different types of institutions in Latvia, inter alia private and smaller higher education institutions, to get a more correct illustration on processes.

Simultaneously, one of the definitions of the non-tenured faculty is actually "part-timers". The share of the elected academic personnel holding posts with workload less than one full workload at the University of Latvia is quite high $-88 \%$, with the largest group (34\%) even having the workload less than 0.25 . Since getting a side job seems to be the usual strategy to cope with a decreasing workload, the academicians might experience a dwindling connection with the institutional quality culture and less possibilities to develop professionally the skills needed for teaching. Simultaneously, when relating to these data, one has to remember that the academic staff of research track is included in these statistics as well.

The unpredictable and volatile workload, combined from multiple positions, can quickly lead to high workloads, especially if the higher education institution can not mitigate the effect by flexible rearrangement of individual portfolios' of positions. High workloads mean not only increased impact of time management efficiency on professional development accessibility, but that less time for professional development can be allocated in general.

The envisaged nation-wide reforms of the career system by integrating academic and research tracks in line with European and international good practice will abolish the current practice of attending to multiple contracts and allow to manage the annual working time, as well as focus on career development of core staff in line with the strategic objectives of the institution.

\section{Conclusions}

The national accountability measures have not yet come into a direct relation to the non-tenured staff members and their inclusion into internal quality culture of the higher education institutions of Latvia. The statistical information on this target group is hard to access both in national and institutional (large, public university) level.

The higher education institutions in Latvia face the same challenges and are addressing the volatility of available funds through strategical operation 
with workload of the faculty staff, ensuring that the core highly qualified staff remains in working relationship with the institution as long as possible.

As a result of country specific contextual situation a considerable share of core faculty is experiencing decrease in workload as well. The academic personnel (including research track academicians) with less than $1 / 4$ of workload is the most populous subgroup at the University of Latvia.

The decreased workload requires a more inclusive approach towards involvement of this staff within institutional quality culture and related professional development activities. The deliberate involvement of the non-tenured staff in internal teaching quality culture at the University of Latvia may wield an improvement of the teaching quality at the university. The higher education institutions should create a targeted policy ensuring that all types of faculty staff (both permanent and non-permanent, part time and full time) receive support to develop professionally.

The leading to institutional quality culture standardized professional development measures in form of further education courses that are efficient in other higher education systems are less effective in addressing the professional development needs of academicians in Latvia, whose background and prior experience is characterized by highly erratic and defragmented individual careers. The courses should be focused and fragmented as well, representing smaller knowledge chunks, that the individual academicians can use to fill in the missing knowledge.

This also means that it is especially important to provide measures and tools that will help the academicians to reflect upon own skills and detect the possible missing knowledge chunks (for example, developing a teacher's portfolio).

Also, the importance of time management skills and efficient time usage requires the most flexible approach to the professional development measures, requiring them to be accessible $24 / 7$, possibly in the form of knowledge data base that can be explored at individual pace. The widely established regular professional development courses are fine if integrated in curricula of doctoral students, which all have comparatively similar experience background to be addressed in standardized way.

If the tenured staff members are aware of the institutional quality culture due to the intensive exposure to it, the non-tenured staff members might benefit from separate introductory course on the respective institutional quality culture within which they should integrate.

Profound reforms of the academic career system have been initiated by the Ministry of Education and Science. Therefore, this would constitute a disadvantageous time for starting any institutional system overhauls.

Indeed, the inclusion of non-tenured staff into internal quality culture of the higher education institution is clearly an accountability driven measure, 
that will eventually increase both the workload of managers, as well as that of academics. Therefore, it is important to ensure that the higher education institution will be able to draw on evidence that the benefits of the introduced accountability measure will cover the associated administrative costs.

Expecting a further rise in transforming power of Neoliberalism and New Public Management in higher education matters, the higher education institutions should be prepared to state ways and describe processes, how the non-tenured staff members are involved in internal quality culture of the institutions.

\section{Acknowledgment}

The publication has been elaborated within postdoctoral research project no. 1.1.1.2/VIAA/2/18/296 (European Regional Development Fund).

\section{References}

Alves, M. G., \& Tomlinson, M. (2020). The changing value of higher education in England and Portugal: Massification, marketization and public good. European Educational Research Journal. https://doi.org/10.1177/1474904120967574

Arnhold, N., Pekkola, E., Püttmann, V., \& Sursock, A. (2018). World Bank Support to Higher Education in Latvia: Volume 3. Academic Careers. World Bank, Washington, DC. (C) World Bank. Retrieved from https://openknowledge.worldbank.org/handle/10986/ 29738 License: CC BY 3.0 IGO.

Benson, W. L., Probst, T. M., Jiang, L., Olson, K. J., \& Graso, M. (2020). Insecurity in the Ivory Tower: Direct and indirect effects of pay stagnation and job insecurity on faculty performance. Economic and Industrial Democracy, 41(3), 693-708. https://doi.org/ $10.1177 / 0143831 X 17734297$

Brignall, S., \& Modell, S. (2000). An institutional perspective on performance measurement and management in the 'new public sector'. Management Accounting Research, 11(3), 281-306.

Broadbent, J. (2018). Large class teaching: How does one go about the task of moderating large volumes of assessment? Active Learning in Higher Education, 19 (2), 173-185.

Central Statistical Bureau. (2020). Official statistics of Latvia. Retrieved from https:// data.stat.gov.lv/pxweb/lv/OSP_PUB/START_IZG_IG_IGP/IGP020/

Erstadt, O., \& Voogt, J. (2018). Chapter 1: Curriculum in the $21^{\text {st }}$ Century: Issues and challenges, Handbook of Information Technology in Primary and Secondary Education, 19-36. Springer. https://doi.org/10.1007/978-3-319-71054-9_1

Harvey, L., \& Jones, S. (2020). Leading educational transformation with sessional staff. In J. Potter \& C. Devecchi (Eds.), Delivering Educational Change in Higher Education: A Transformative Approach for Leaders and Practitioners. 104-115. Routledge. 10.4324/9780429053405-9

Hood, C. (1995). The 'new public management' in the 1980s: Variations on a theme. Accounting, Organizations and Society, 29(2-3), 93-109. 
Jaschik, S., \& Lederman, D. (2015). The 2015 Inside Higher Ed survey of college \& university chief academic officers. Washington: Insider Higher Ed \& Gallup. Retrieved from https:// www.insidehighered.com/news/survey/2015-survey-chief-academic-officers

Kezar, A. (2013). Examining Non-Tenure Track Faculty Perceptions of How Departmental Policies and Practices Shape Their Performance and Ability to Create Student Learning at Four-Year Institutions. Research in Higher Education, 54(5), 571-598. Retrieved from http://www.jstor.org/stable/23470964

Kezar, A., \& Maxey, D. (2014). Student Outcomes Assessment Among the New Non-TenureTrack Faculty Majority. National Institute for Learning Outcomes Assessment. Retrieved fromhttp://citeseerx.ist.psu.edu/viewdoc/download?doi $=10.1 .1 .564 .8798 \&$ rep $=$ rep1\& type $=$ pdf

LETA. (2013). ES mudina augstskolās pasniedzēju mācīšanas prasmju pilnveidei veltît tikpat daudz uzmanības kā pētniecībai [The EU encourages universities to pay as much attention to improving their teaching skills as to improving their research skills]. Retrieved from: multimedia portal "Es\&ES" that is managed by the National News Agency LETA in cooperation with European Parliament http://www.leta.lv/es/ item/1332C6C1-D518-BAB8-11D6-CEE6B6AFF09F/jaunumi:feature/

Lethbridge, J. (2015). Has Neoliberalism defined Postmodernity? History Initiates, 3(1), 68-77. Retrieved from: https://www.mq.edu.au/pubstatic/public/download.jsp?id= 212979

Madsen, M. (2020). Competitive/comparative governance mechanisms beyond marketization: A refined concept of competition in education governance research. European Educational Research Journal. https://doi.org/10.1177/1474904120958922

McCormick, A., C. (2019). Beyond Performance Indicators: Reforming Higher Education Evaluation Systems to Promote Improvement. International Journal of Chinese Education, 60-72. https://doi.org/10.1163/22125868-12340105

McCowan, T. (2016). Three dimensions of equity of access to higher education, Compare: A Journal of Comparative and International Education, 46(4), 645-665. DOI: 10.1080/ 03057925.2015.1043237

Ministry of Education and Science of the Republic of Latvia. (2020a). Statistika par augstāko izglītību. [Statistics on higher education]. Retrieved from: https://www.izm. gov.lv/lv/statistika-par-augstako-izglitibu

Ministry of Education and Science of the Republic of Latvia. (2020b) Pārskats par Latvijas augstāko izglìtibu 2019. gadā [Report on Higher Education in Latvia in 2019]. Retrieved from: https://www.izm.gov.lv/lv/media/2122/download

Ministry of Education and Science of the Republic of Latvia. (2019) Pārskats par Latvijas augstāko izglīīibu 2018. gadā [Report on Higher Education in Latvia in 2018]. Retrieved from https://www.izm.gov.lv/lv/media/2137/download

Narayan, A., K. (2020). The development and use of performance measures in New Zealand tertiary education institutions. Accounting History, 25(2), 193-218. https://doi.org/ $10.1177 / 1032373219842383$

Nica, E. (2018). Has the shift to overworked and underpaid adjunct faculty helped education outcomes? Educational Philosophy and Theory, 50(3), 213-216. 10.1080/ 00131857.2017.1300026

Ortagus, J. C., Kelchen, R., Rosinger, K., \& Voorhees, N. (2020). Performance-Based Funding in American Higher Education: A Systematic Synthesis of the Intended and Unintended Consequences. Educational Evaluation and Policy Analysis, 42(4), 520550. https://doi.org/10.3102/0162373720953128 
Osborne, S. P., Radnor, Z., \& Nasi, G. (2013). A New Theory for Public Service Management? Toward a (Public) Service-Dominant Approach. American Review of Public Administration, 43(2), 135-158.

Rege, C., \& Nicole, M. (2017). From content-centred to learning-centred approaches: Shifting educational paradigm in higher education. Journal of Educational Administration and History, 49(1), 72-86. 10.1080/00220620.2017.1252737

Riga Technical University. (2010). Akadēmiskās bakalaura studiju programmas K,BLO (43524) "Ķīmijas tehnoloǵija" Pašnovērtējuma ziņojums. 2009./2010. m.g., Materiālzinātnes un lietišķās kīmijas fakultāte. [Self-evaluation report of the academic backelor study program KBBLO (43524) "Chemical technology". Year of study 2009/2010. Faculty of Material Sciences and Applied Chemistry.] Retrieved from https://www.rtu.lv/ writable/public_files/RTU_kbl0_2009_2010_pz.pdf

Savic, M. (2020). The Dawn of the Academic Revolution: An Individual Contribution to Shaping the Future of Universities. World Futures Review, 12(4), 385-395. https://doi.org/ $10.1177 / 1946756720976703$

Shields, R. (2019). The sustainability of international higher education: Student mobility and global climate change. Journal of Cleaner Production, 217, 594-602. https://doi.org/ 10.1016/j.jclepro.2019.01.291

Tight, M. (2019). Mass Higher Education and Massification. Higher Education Policy 32, 93-108. https://doi.org/10.1057/s41307-017-0075-3

University of Latvia. (2017). Studiju virziena Fizika, Materiālzinātne, Matemātika un statistika pašnovērtējuma ziṇojums 2016./2017. akadēmiskais gads. Fizikas un matemātikas fakultāte. [Self-evaluation report of Physics, Material Science and Statistics study direction 2016/2017. Faculty of Physics and Mathematics.] Retrieved from: https://www.lu.lv/ fileadmin/user_upload/lu_portal/dokumenti/parskati-un-zinojumi/Pasnovertejumi/ 2017/FIZIKA_MATEMATIKA_2017_PUB.pdf

University of Latvia. (2008). Latvijas Universitātes modernizācijas plāns, pārvarot ekonomi$s k \bar{s} s$ krizes radito iespaidu uz $L U$ attistibu. [Modernization plan of the University of Latvia, overcoming the impact of the economic crisis on the development of the University of Latvia]. Retrieved from: http://fizmati.lv/forums/attachment.php?aid $=357$

University of Latvia. (2004). Latvijas Universitātes Attistibas stratēǵija. [The Development Strategy of the University of Latvia]. Retrieved from: www.lu.lv/fileadmin/user_upload/ lu_portal/dokumenti/strategijas-un-koncepcijas/attistibas-strategija.doc

Valli, L., \& Buese, D. (2007). The Changing Roles of Teachers in an Era of High-Stakes Accountability. American Educational Research Journal, 44(3), 519-558. https://doi.org/ 10.3102/0002831207306859

Xu, D. (2019). Academic Performance in Community Colleges: The Influences of PartTime and Full-Time Instructors. American Educational Research Journal, 56(2), 368406. https://doi.org/10.3102/0002831218796131

World Bank. (2020). Technical support to the Ministry of Education and Science of Latvia. Academic Career Framework for Latvia: Ideas Paper. Retrieved from the Ministry of Education and Science of the Republic of Latvia website. Retrieved from: https://www. izm.gov.lv/lv/media/4729/download 